\title{
Horazens Oden,
}

\author{
$\ddot{u} b$ e r s e t $z t$
}

von

Karl Wilhelm Ramler.

Zweite Auflage.

$$
\text { B e } r 1 \text { i } n \text {, }
$$

S andersche Buchhandlung

(Kurstrasse, No. 51.)

1818 . 
